Federal Reserve Bank of Minneapolis

Research Department Staff Report 403

April 2008

\title{
Optimal Fiscal and Monetary Policy: Equivalence Results*
}

\author{
Isabel Correia \\ Banco de Portugal, \\ Universidade Catolica Portuguesa, \\ and Centre for Economic Policy Research \\ Juan Pablo Nicolini \\ Universidad Di Tella \\ Pedro Teles \\ Banco de Portugal, \\ Universidade Catolica Portuguesa, \\ Centre for Economic Policy Research, \\ and Federal Reserve Bank of Minneapolis
}

\begin{abstract}
In this article, we analyze the implications of price-setting restrictions for the conduct of cyclical fiscal and monetary policy. We consider standard monetary economies that differ in the price-setting restrictions imposed on the firms. We show that, independently of the degree or type of price stickiness, it is possible to implement the same efficient set of allocations and that each allocation in that set is implemented with policies that are also independent of the price stickiness. In this sense, environments with different price-setting restrictions are equivalent.
\end{abstract}

\footnotetext{
* Reprinted by permission from Journal of Political Economy 116 (February 2008): 141-70. The authors thank Fernando Alvarez, V. V. Chari, Larry Christiano, Constantino Hevia, Andy Neumeyer, Sergio Rebelo, Julio Rotemberg, Tom Sargent, Stephanie Schmitt-Grohé, Martin Uribe, and especially Patrick Kehoe, John Cochrane, Monika Piazzesi, and Ivan Werning. They are also thankful for the comments of the anonymous referees and those of seminar participants at the University of Chicago, the University of Pennsylvania, and New York University. The authors gratefully acknowledge the Federal Reserve Bank of Chicago, the Federal Reserve Bank of Minneapolis, and the financial support of Fundação de Ciência e Teconologia for Correia and Teles and Agencia Nacional de Promoción Científica y Tecnológica for Nicolini. The views expressed herein are those of the authors and not necessarily those of the Federal Reserve Bank of Minneapolis or the Federal Reserve System.
} 


\section{Introduction}

How relevant are sticky prices in conducting monetary policy? This question has been at the center of the stabilization policy debate for decades. Recently there has been a renewed interest in it (see Woodford, 2003). We address this question and conclude that, in contrast with the conventional wisdom, once fiscal policy is taken into account, the extent of the nominal rigidity does not matter for the conduct of monetary policy. We show that neither the optimal allocation nor the optimal policy depends on the price rigidity. This is the main result of the article.

We analyze the optimal policy problem in a dynamic general equilibrium model with money and taxes, following the dynamic Ramsey literature after Lucas and Stokey (1983) and Chari, Christiano and Kehoe (1991). This approach allows us to study the distortions created by price stickiness in a model in which other distortions are present, in particular, the need to raise distortionary taxation to finance government expenditures. This is important, since, in general, the optimal way to deal with a distortion depends on other existing distortions.

As a benchmark, we consider a model that is very similar to the perfectly competitive model of Lucas and Stokey (1983), where prices are fully flexible. They consider a stochastic production economy without capital, with cash and credit goods. In their model, the government finances exogenous expenditures with revenue from labor income taxes and seigniorage and issues statecontingent debt. We depart from Lucas and Stokey by assuming that the fiscal instruments are both income and consumption taxes and that government debt is noncontingent nominal debt. Because we want to consider firms that are price setters, we assume that final consumption is a composite good, aggregated over a continuum of goods with the Dixit-Stiglitz aggregator. Each good is produced by a monopolist, and all producers share the same labor-only linear technology.

This standard flexible price economy is compared to economies in which firms are restricted 
in setting prices, but are otherwise identical. In most of the analysis, we assume that a fraction of firms set prices one period in advance, but we extend the analysis to other price-setting restrictions such as in Calvo (1983), where the effects of monetary policy shocks are persistent. In general, for arbitrarily given monetary and fiscal policies, the equilibrium allocations depend on the extent of price stickiness. As we show, however, this dependence vanishes once optimal policy is considered. Under the optimal policy, the allocations are invariant to the extent of the price stickiness. Furthermore, there is a sense in which the optimal policy is also invariant to the extent of the rigidity: as we vary the degree of price stickiness, the same policy can implement the optimal allocation.

The set of fiscal policy instruments is crucial for the results. In related work, Benigno and Woodford (2003), Schmitt-Grohé and Uribe (2004), and Siu (2004) find a nontrivial dependence of optimal policy on the extent of price stickiness. They make similar assumptions on the fiscal and debt instruments, but they consider only one tax, on either consumption or labor income. Once we combine state-contingent labor income taxes (available in the models of Siu and Schmitt-Grohé and Uribe) with consumption taxes (available in the model of Benigno and Woodford), optimal policy is independent of the extent of the price stickiness.

With state-contingent consumption and labor income taxes, it is possible to neutralize the effect of the price stickiness, so that any allocation that is implementable under flexible prices is also implementable under sticky prices. This is clear once we show that under flexible prices it is possible to implement each equilibrium allocation with policies that induce constant producer prices. Under those policies, if restrictions on the setting of prices were to be imposed, such as prices set in advance or staggered prices as in Calvo (1983), such restrictions would have no impact.

Under sticky prices, the set of implementable allocations includes the set under flexible prices, but it also includes allocations other than those. In particular, because firms may be 
restricted in different ways in their setting of prices, there are equilibrium allocations in which otherwise identical firms set different prices and therefore supply different quantities. We show that such allocations are dominated in welfare terms by the allocations under flexible prices, so that the optimal allocation is the same under sticky prices as under flexible prices.

A more precise way to understand this result is as follows. In the model, there is a continuum of firms that use labor to produce imperfectly substitutable goods. These goods can be interpreted as intermediate goods that are aggregated into two composite final goods: a cash good and a credit good. Production is efficient when a marginal increase in labor in the production of each of the intermediate goods has the same marginal impact on the production of the final good. In equilibrium, this is the case if the price of each of the intermediate goods is the same. Under flexible prices, all firms set the same price, so that only productive-efficient allocations can be implemented. Under sticky prices, instead, it is possible to implement many productive-inefficient allocations as well. We show that the Ramsey allocation under sticky prices must be productive-efficient, using an argument similar to the one used in Diamond and Mirrlees (1971) to prove the optimality of zero taxes on intermediate goods. It follows that the optimal allocations under sticky and flexible prices coincide.

One implication of our findings is that the results in the literature on the behavior of optimal allocations under flexible prices, as in Lucas and Stokey (1983) and Chari et al. (1991), immediately extend to environments with nominal rigidities. Under flexible prices, there are typically a variety of ways to decentralize the optimal allocation. One of these has constant producer prices, but others do not. The policy that decentralizes the optimal allocation with constant prices is the same under flexible and sticky prices.

The article also extends the literature on optimal monetary policy under sticky prices by 
explicitly considering both fiscal and monetary policies. The benchmark in that literature (for example, Rotemberg and Woodford 1997; Clarida, Gali, and Gertler 1999) is to assume that the government can tax in a lump-sum fashion in order to finance a subsidy to production that eliminates the markup distortion. It is also common to abstract from the money demand distortion by assuming that the economy is the cashless limit of a sequence of monetary economies. By replicating flexible prices, it is possible to eliminate the only remaining distortion, the nominal rigidity, and achieve the first-best allocation. In contrast, in our article we have a number of distortions that cannot be overcome, so that the first-best allocation is not feasible.

Another branch of the literature, aiming to abstract from fiscal policy altogether, allows for lump-sum taxes but not for distortionary taxes or subsidies (see Ireland 1996; Adão, Correia, and Teles 2003; Khan, King, and Wolman 2003). Since it is no longer possible to eliminate the markup distortion, the problem is then a second-best problem. ${ }^{1}$ For example, Adão et al. show that under sticky prices, with such restrictions on the class of fiscal policies, the optimal flexible price allocation is implementable but not optimal. ${ }^{2}$ As we show in this article, the joint consideration of both fiscal and monetary policies reverses this result.

As already mentioned, the work most closely related to ours is by Benigno and Woodford (2003), Schmitt-Grohé and Uribe (2004), and Siu (2004). They address the same issues we do but assume that only one tax can be used. With that restriction on fiscal instruments, it is no longer possible to implement under sticky prices the set of flexible price allocations. The result is a third-best solution in which the extent of the nominal rigidity matters for both optimal policies and allocations.

Our analysis proceeds as follows: We describe the model economy in Section II. We assume that a share of firms set prices one period in advance. In Section III, we characterize the sets 
of implementable allocations, prices, and policies under flexible prices. We show that the set of allocations can be implemented with producer prices that are constant over time. Section IV contains the main results. We show that the degree of price rigidity is irrelevant in determining both the optimal allocation and the policies that implement it. In Section V, we interpret the results by allowing for good-specific taxes, which can affect the wedges between the differentiated goods in the same way as policy under sticky prices. We relate the results to the standard result on the optimality of productive efficiency in Diamond and Mirrlees (1971). In Section VI.A, we show that the results are robust to alternative price-setting restrictions, and in Section VI.B, we show that the equivalence results would not hold if restrictions on the tax instruments were to be imposed, as in related literature. We also discuss optimal policies and the relevance of alternative fiscal instruments. Section VII contains concluding remarks.

\section{The economy}

The economy is inhabited by identical households, a continuum of firms indexed by $i \in[0,1]$, and a government. Time is discrete, and in each time period $t=1,2 \ldots$, one of finitely many events $s_{t} \in S_{t}$ occurs. The history of events up to period $t,\left(s_{0}, s_{1}, \ldots, s_{t}\right)$, is denoted by $s^{t} \in S^{t}$, and the initial realization $s_{0}$ is given. Let $\pi\left(s^{t}\right)$ be the probability of the occurrence of state $s^{t}$.

Each firm uses labor $n_{i}\left(s^{t}\right)$ to produce a distinct, perishable good $y_{i}\left(s^{t}\right)$ that can be used for private consumption as a cash good $c_{1 i}\left(s^{t}\right)$, as a credit good $c_{2 i}\left(s^{t}\right)$, or for public consumption $g_{i}\left(s^{t}\right)$. The technology is given by

$$
c_{1 i}\left(s^{t}\right)+c_{2 i}\left(s^{t}\right)+g_{i}\left(s^{t}\right)=y_{i}\left(s^{t}\right)=A\left(s^{t}\right) n_{i}\left(s^{t}\right),
$$

where $A\left(s^{t}\right)$ is the productivity that is common across goods. 
Households draw utility from composite cash goods $C_{1}\left(s^{t}\right)$ and credit goods $C_{2}\left(s^{t}\right)$ and disutility from aggregate labor $N\left(s^{t}\right)$, according to the following function that has the standard properties:

$$
\sum_{t=0}^{\infty} \sum_{s^{t}} \beta^{t} \pi\left(s^{t}\right) u\left(C_{1}\left(s^{t}\right), C_{2}\left(s^{t}\right), N\left(s^{t}\right)\right),
$$

with

$$
\begin{aligned}
& C_{1}\left(s^{t}\right)=\left[\int_{0}^{1} c_{1 i}\left(s^{t}\right)^{\frac{\theta-1}{\theta}} d i\right]^{\frac{\theta}{\theta-1}}, \theta>1, \\
& C_{2}\left(s^{t}\right)=\left[\int_{0}^{1} c_{2 i}\left(s^{t}\right)^{\frac{\theta-1}{\theta}} d i\right]^{\frac{\theta}{\theta-1}}, \theta>1,
\end{aligned}
$$

and

$$
N\left(s^{t}\right)=\int_{0}^{1} n_{i}\left(s^{t}\right) d i
$$

Aggregate government purchases $G\left(s^{t}\right)$,

$$
G\left(s^{t}\right)=\left[\int_{0}^{1} g_{i}\left(s^{t}\right)^{\frac{\theta-1}{\theta}} d i\right]^{\frac{\theta}{\theta-1}}, \theta>1
$$

are exogenous and must be financed with state-contingent consumption taxes $\tau^{c}\left(s^{t}\right)$, taxes on labor income $\tau^{n}\left(s^{t}\right)$, and taxes on profits $\tau^{d}\left(s^{t}\right)$ and by printing money $M\left(s^{t}\right)$. We restrict public nominal debt to be of one-period maturity and to be state-noncontingent.

Note that each good enters with the same weight in the Dixit-Stiglitz aggregators. In addition, the technology shock is the same for all goods. These symmetry assumptions are standard in the literature.

For simplicity only, we assume that profits are fully taxed, $\tau^{d}\left(s^{t}\right)=1$, and that initial wealth is zero, which is equivalent to assuming that it also is fully taxed. ${ }^{3}$ Our results are unchanged if we 
assume that there are bounds, which may be zero, on the tax rates on both profits and initial wealth. With such bounds, the proofs follow a logic similar to that used here but are more cumbersome.

Households The households start period $t$ with nominal wealth $\mathbb{W}\left(s^{t}\right)$. They decide to buy money balances $M\left(s^{t}\right)$, risk-free nominal bonds $\bar{B}\left(s^{t}\right)$ that pay $R\left(s^{t}\right) \bar{B}\left(s^{t}\right)$ units of money one period later, and $B\left(s^{t+1}\right)$ units of state-contingent nominal securities. Here the only role of statecontingent debt is to define state-contingent prices. We assume that the state-contingent bonds are traded only among households so that they are in zero net supply. These bonds pay one unit of money at the beginning of period $t+1$ in state $s^{t+1}$ and cost $Q\left(s^{t+1} \mid s^{t}\right)$ units of money in state $s^{t}$. Thus, the purchases of assets by the households must satisfy

$$
M\left(s^{t}\right)+\bar{B}\left(s^{t}\right)+\sum_{s^{t+1} \mid s^{t}} Q\left(s^{t+1} \mid s^{t}\right) B\left(s^{t+1}\right) \leq \mathbb{W}\left(s^{t}\right)
$$

At the end of the period, the households receive labor income $W\left(s^{t}\right) N\left(s^{t}\right)$, where $W\left(s^{t}\right)$ is the nominal wage. Note that households do not receive profits from the firms because profits are fully taxed. If we let $p_{i}\left(s^{t}\right)$ be the producer price of good $i$ in units of money and

$$
p_{i}^{c}\left(s^{t}\right) \equiv\left[1+\tau^{c}\left(s^{t}\right)\right] p_{i}\left(s^{t}\right)
$$

be the consumer price of good $i$ gross of consumption taxes, then the evolution of nominal wealth is governed by 


$$
\begin{aligned}
\mathbb{W}\left(s^{t+1}\right) & =R\left(s^{t}\right) \bar{B}\left(s^{t}\right)+B\left(s^{t+1}\right)+M\left(s^{t}\right)-\int_{0}^{1} p_{i}^{c}\left(s^{t}\right) c_{1 i}\left(s^{t}\right) d i \\
& -\int_{0}^{1} p_{i}^{c}\left(s^{t}\right) c_{2 i}\left(s^{t}\right) d i+\left[1-\tau^{n}\left(s^{t}\right)\right] W\left(s^{t}\right) N\left(s^{t}\right), \text { for } t \geq 0 .
\end{aligned}
$$

Money, $M\left(s^{t}\right)$, is used to purchase consumption of the cash good, $C_{1}\left(s^{t}\right)$, according to the cash-in-advance constraint

$$
P^{c}\left(s^{t}\right) C_{1}\left(s^{t}\right) \leq M\left(s^{t}\right)
$$

where $P^{c}\left(s^{t}\right)$ is

$$
P^{c}\left(s^{t}\right)=\left[\int_{0}^{1}\left[p_{i}^{c}\left(s^{t}\right)\right]^{1-\theta} d i\right]^{\frac{1}{1-\theta}}
$$

which is the money cost to buy one unit of the composite goods, gross of consumption taxes.

Households choose the sequence $\left\{c_{1 i}\left(s^{t}\right), c_{2 i}\left(s^{t}\right), N\left(s^{t}\right)\right\}_{t=0}^{\infty}$ that maximizes utility, (2), satisfying (3), (4), (7), (8) together with a no-Ponzi games condition, and (9). The following are necessary household marginal conditions:

$$
\frac{c_{1 i}\left(s^{t}\right)}{C_{1}\left(s^{t}\right)}=\left[\frac{p_{i}^{c}\left(s^{t}\right)}{P^{c}\left(s^{t}\right)}\right]^{-\theta}, t \geq 0
$$

and

$$
\frac{c_{2 i}\left(s^{t}\right)}{C_{2}\left(s^{t}\right)}=\left[\frac{p_{i}^{c}\left(s^{t}\right)}{P^{c}\left(s^{t}\right)}\right]^{-\theta}, t \geq 0,
$$

that determine the demand for each good as a function of the relative price and the consumption 
of the composite good,

$$
\frac{u_{C_{1}}\left(s^{t}\right)}{u_{C_{2}}\left(s^{t}\right)}=R\left(s^{t}\right) \geq 1, t \geq 0,
$$

that set the marginal rate of substitution between cash and credit goods equal to its relative price distorted by the nominal interest rate. The inequality $R\left(s^{t}\right) \geq 1$ must hold in any equilibrium, since otherwise households could make arbitrarily large profits by issuing bonds and holding money. The household marginal conditions also include the intratemporal condition

$$
-\frac{u_{C_{2}}\left(s^{t}\right)}{u_{N}\left(s^{t}\right)}=\frac{P^{c}\left(s^{t}\right)}{\left[1-\tau^{n}\left(s^{t}\right)\right] W\left(s^{t}\right)}, t \geq 0,
$$

where it is apparent how consumption and labor income taxes affect the marginal choice between labor and the credit good, as well as the intertemporal conditions

$$
Q\left(s^{t+1} \mid s^{t}\right)=\beta \pi\left(s^{t+1} \mid s^{t}\right) \frac{u_{C_{1}}\left(s^{t+1}\right)}{u_{C_{1}}\left(s^{t}\right)} \frac{P^{c}\left(s^{t}\right)}{P^{c}\left(s^{t+1}\right)}, t \geq 0
$$

and

$$
\frac{u_{C_{1}}\left(s^{t}\right)}{P^{c}\left(s^{t}\right)}=\beta R\left(s^{t}\right) E_{t}\left[\frac{u_{C_{1}}\left(s^{t+1}\right)}{P^{c}\left(s^{t+1}\right)}\right], t \geq 0
$$

for the optimal choice of the one-period-ahead state-contingent and noncontingent nominal assets.

Clearly, these last two equations imply that holding a risk-free nominal bond must be equivalent to holding a full array of one-period state-contingent assets, or

$$
\frac{1}{R\left(s^{t}\right)}=\sum_{s^{t+1} \mid s^{t}} Q\left(s^{t+1} \mid s^{t}\right), t \geq 0
$$

Let $Q\left(s^{r} \mid s^{t}\right)=Q\left(s^{t+1} \mid s^{t}\right) \cdots Q\left(s^{r} \mid s^{r-1}\right)$ be the price of one unit of money at $s^{r}$ in units of money at 
$s^{t}$. Given the no-Ponzi games condition and the condition that $B\left(s^{t+1}\right)=0$ for all $s^{t+1}$, optimality also requires that the transversality condition

$$
\lim _{T \rightarrow \infty} \sum_{s^{T+1} \mid s^{t}} Q\left(s^{T+1} \mid s^{t}\right)\left[M\left(s^{T+1}\right)+\bar{B}\left(s^{T+1}\right)\right]=0
$$

hold. Then the budget constraints can be written with equality as ${ }^{4}$

$$
\begin{aligned}
& \sum_{r=t}^{\infty} \sum_{s^{r}} \frac{Q\left(s^{r} \mid s^{t}\right)}{R\left(s^{r}\right)}\left\{P^{c}\left(s^{r}\right)\left[C_{1}\left(s^{r}\right)+C_{2}\left(s^{r}\right)\right]\right\}+ \\
& \sum_{r=t}^{\infty} \sum_{s^{r}} \frac{Q\left(s^{r} \mid s^{t}\right)}{R\left(s^{r}\right)}\left\{M\left(s^{r}\right)\left[R\left(s^{r}\right)-1\right]-\left[1-\tau^{n}\left(s^{r}\right)\right] W\left(s^{r}\right) N\left(s^{r}\right)\right\} \\
= & \mathbb{W}\left(s^{t}\right) .
\end{aligned}
$$

We can replace in these budget constraints the intertemporal prices $Q\left(s^{r} \mid s^{t}\right)$ using (15) and use the intertemporal conditions (16), the intratemporal conditions (13) and (14), and the cash-in-advance constraints $(9)$, as well as $B\left(s^{t+1}\right)=0$, to write the budget conditions as

$$
\begin{aligned}
& E_{t} \sum_{r=t}^{\infty} \beta^{r-t}\left[u_{C_{1}}\left(s^{r}\right) C_{1}\left(s^{r}\right)+u_{C_{2}}\left(s^{r}\right) C_{2}\left(s^{r}\right)+u_{N}\left(s^{r}\right) N\left(s^{r}\right)\right] \\
& \quad=u_{C_{1}}\left(s^{t}\right) \frac{\mathbb{W}\left(s^{t}\right)}{P^{c}\left(s^{t}\right)}, t \geq 0
\end{aligned}
$$

where

$$
\begin{aligned}
\mathbb{W}\left(s^{t}\right)= & M\left(s^{t-1}\right)+R\left(s^{t-1}\right) \bar{B}\left(s^{t-1}\right) \\
& -P^{c}\left(s^{t-1}\right)\left[C_{1}\left(s^{t-1}\right)+C_{2}\left(s^{t-1}\right)+\frac{u_{N}\left(s^{t-1}\right)}{u_{C_{2}}\left(s^{t-1}\right)} N\left(s^{t-1}\right)\right],
\end{aligned}
$$


for $t \geq 1$, and $\mathbb{W}_{0}=0$.

It is worth noting that the implementability conditions (19) do not depend on the pricesetting restrictions. ${ }^{5}$ Note also that equation (19) for $t=0$ is the standard implementability constraint. When the government is allowed to issue state-contingent debt, as in Lucas and Stokey (1983), the constraints from period 1 on are satisfied by the choice of the supply of state-contingent assets, for all $s^{t}$, so that there is a single, period 0 implementability constraint. Here, instead, that supply must be zero.

The Government Given the exogenous evolution of aggregate government purchases, $G\left(s^{t}\right)$, and the consumer prices, $p_{i}^{c}\left(s^{t}\right)$, the government minimizes the expenditure $\int_{0}^{1} p_{i}^{c}\left(s^{t}\right) g_{i}\left(s^{t}\right) d i$ needed to obtain $G\left(s^{t}\right)$ given by (6) by deciding according to

$$
\frac{g_{i}\left(s^{t}\right)}{G\left(s^{t}\right)}=\left[\frac{p_{i}^{c}\left(s^{t}\right)}{P^{c}\left(s^{t}\right)}\right]^{-\theta} .
$$

Given full profit taxation, $\tau^{d}\left(s^{t}\right)=1$ for all $s^{t}$, a government policy consists of public consumption of each good, $g_{i}\left(s^{t}\right)$; money supply, $M\left(s^{t}\right)$; taxes on consumption and labor income, $\tau^{c}\left(s^{t}\right)$ and $\tau^{n}\left(s^{t}\right)$; nominal interest rates, $R\left(s^{t}\right)$; and debt supply, $\bar{B}^{g}\left(s^{t}\right)$ for all $t \geq 0$ and states $s^{t} \in S^{t}$.

If the budget constraint of the households and the market-clearing conditions hold, then the budget constraint of the government also holds.

Firms Each good $i \in[0,1]$ is produced by a monopolist firm that faces a constant elasticity demand function 


$$
y_{i}\left(s^{t}\right)=\left[\frac{p_{i}^{c}\left(s^{t}\right)}{P^{c}\left(s^{t}\right)}\right]^{-\theta} Y\left(s^{t}\right)
$$

obtained from the demand functions for the private and public goods, (11), (12) and (20), where $Y\left(s^{t}\right)=C_{1}\left(s^{t}\right)+C_{2}\left(s^{t}\right)+G\left(s^{t}\right)$. There are two types of firms: sticky price firms $i \in[0, \alpha]$, with $\alpha \in[0,1)$, set prices one period in advance; the remaining $1-\alpha$ flexible price firms $i \in(\alpha, 1]$, choose prices contemporaneously. The flexible price firms choose prices to maximize profits at each period $t \geq 0$,

$$
p_{i}\left(s^{t}\right) y_{i}\left(s^{t}\right)-W\left(s^{t}\right) n_{i}\left(s^{t}\right)
$$

given the technology (1) and the demand function (21) where $p_{i}^{c}\left(s^{t}\right)=\left[1+\tau^{c}\left(s^{t}\right)\right] p_{i}\left(s^{t}\right)$.

Because all monopolists face the same demand curve and have the same technology, all set a common price

$$
p_{i}\left(s^{t}\right) \equiv p_{f}\left(s^{t}\right)=\frac{\theta}{\theta-1} \frac{W\left(s^{t}\right)}{A\left(s^{t}\right)}, \text { for all } i \in[\alpha, 1]
$$

equal to a constant markup over marginal cost.

The sticky price firms that set prices one period in advance sell the output on demand at the preset prices. In period 0 , they charge an exogenously given price $p_{-1}$. For $t \geq 1$, they choose a period $t$ price $p_{i}\left(s^{t-1}\right)$, that does not depend on the contemporaneous shocks, in order to maximize profits $^{6}$

$$
\sum_{s^{t+1} \mid s^{t-1}} Q\left(s^{t+1} \mid s^{t-1}\right)\left[p_{i}\left(s^{t-1}\right) y_{i}\left(s^{t}\right)-W\left(s^{t}\right) n_{i}\left(s^{t}\right)\right]
$$

subject to (1) and (21), where $p_{i}^{c}\left(s^{t}\right)=\left[1+\tau^{c}\left(s^{t}\right)\right] p_{i}\left(s^{t-1}\right)$. 
The following condition, simplified using (17), characterizes the solution of this problem:

$$
\sum_{s^{t} \mid s^{t-1}}\left\{\frac{Q\left(s^{t} \mid s^{t-1}\right) Y\left(s^{t}\right)}{R\left(s^{t}\right)}\left[\frac{P^{c}\left(s^{t}\right)}{1+\tau^{c}\left(s^{t}\right)}\right]^{\theta}\left[p_{i}\left(s^{t-1}\right)-\frac{\theta}{(\theta-1)} \frac{W\left(s^{t}\right)}{A\left(s^{t}\right)}\right]\right\}=0
$$

for $t \geq 1$.

With (13) and (15), this condition can be rearranged so that the expression for the common price chosen by the sticky firms for period $t, p_{s}\left(s^{t-1}\right)$, is

$$
p_{i}\left(s^{t-1}\right) \equiv p_{s}\left(s^{t-1}\right)=\frac{\theta}{(\theta-1)} E_{t-1}\left[v\left(s^{t}\right) \frac{W\left(s^{t}\right)}{A\left(s^{t}\right)}\right], t \geq 1
$$

for all $i \in[0, \alpha]$, where

$$
v\left(s^{t}\right)=\frac{u_{C_{2}}\left(s^{t}\right)\left[1+\tau^{c}\left(s^{t}\right)\right]^{-\theta}\left[P^{c}\left(s^{t}\right)\right]^{\theta-1} A\left(s^{t}\right) N\left(s^{t}\right)}{E_{t-1}\left\{u_{C_{2}}\left(s^{t}\right)\left[1+\tau^{c}\left(s^{t}\right)\right]^{-\theta}\left[P^{c}\left(s^{t}\right)\right]^{\theta-1} A\left(s^{t}\right) N\left(s^{t}\right)\right\}},
$$

so that the sticky price firms charge a markup over the expected value of a weighted marginal cost. This condition implies that the price set by the firms one period in advance is a weighted conditional average of the price set by the flexible price firms,

$$
p_{s}\left(s^{t-1}\right)=E_{t-1}\left[v\left(s^{t}\right) p_{f}\left(s^{t}\right)\right], t \geq 1 \text {. }
$$

Market clearing Demand must be equal to supply for each good $i$ and for labor according to (1) and (5), which we repeat here:

$$
c_{1 i}\left(s^{t}\right)+c_{2 i}\left(s^{t}\right)+g_{i}\left(s^{t}\right)=A\left(s^{t}\right) n_{i}\left(s^{t}\right)
$$


and

$$
N\left(s^{t}\right)=\int_{0}^{1} n_{i}\left(s^{t}\right) d i
$$

The market-clearing conditions for the nominal debt markets are

$$
\bar{B}\left(s^{t}\right)=\bar{B}^{g}\left(s^{t}\right)
$$

and

$$
B\left(s^{t+1}\right)=0 .
$$

Equilibria An equilibrium in an economy with $0 \leq \alpha<1$, given $p_{-1}$, is an allocation $\left\{C_{1}\left(s^{t}\right), C_{2}\left(s^{t}\right), N\left(s^{t}\right)\right\}_{t=0}^{\infty}$, all $s^{t} ; \quad\left\{c_{1 i}\left(s^{t}\right), c_{2 i}\left(s^{t}\right), n_{i}\left(s^{t}\right)\right\}_{t=0}^{\infty}$, all $s^{t}, \quad i \in[0,1] ;$ debt levels $\left\{\bar{B}\left(s^{t}\right), B\left(s^{t+1}\right)\right\}_{t=0}^{\infty}$, all $s^{t}$; and prices and policies

$$
\begin{aligned}
& \left\{p_{i}\left(s^{t}\right), P^{c}\left(s^{t}\right), W\left(s^{t}\right), Q\left(s^{t+1} \mid s^{t}\right), g_{i}\left(s^{t}\right), G\left(s^{t}\right), M\left(s^{t}\right), \tau^{c}\left(s^{t}\right), \tau^{n}\left(s^{t}\right),\right. \\
& \left.\bar{B}^{g}\left(s^{t}\right), R\left(s^{t}\right)\right\}_{t=0}^{\infty},
\end{aligned}
$$

all $s^{t}$, all $i$, that solve the problems of the households, the firms, and the government and such that markets clear.

The set of equilibria is characterized by the household marginal conditions (10), (11), (12), (13), (14), (15), (16), and the cash-in-advance constraints (9), together with the nonnegativity constraint on the nominal interest rates, which can be written as

$$
u_{C_{1}}\left(s^{t}\right) \geq u_{C_{2}}\left(s^{t}\right)
$$


given $p_{-1}$, the price-setting conditions (22) and (25) characterize the optimal behavior of the firms; the government purchases public goods according to (20) and chooses the other policy variables, satisfying the budget constraints for every $s^{t}$, which, given the market-clearing conditions, can be written as the household budget constraints (19); finally, the market-clearing conditions (27), (28), (29), and (30) must hold.

As we show in the following lemma, in any equilibrium the quantities produced by the flexible price firms are equal across those firms, and similarly for the sticky price firms.

Lemma 1. (a) In any equilibrium with $\alpha=0$,

$$
c_{1 i}\left(s^{t}\right)=C_{1}\left(s^{t}\right), c_{2 i}\left(s^{t}\right)=C_{2}\left(s^{t}\right) ; g_{i}\left(s^{t}\right)=G\left(s^{t}\right) ; n_{i}\left(s^{t}\right)=N\left(s^{t}\right) \text { for all } i \in[0,1] \text {. }
$$

(b) In any equilibrium with $\alpha \in(0,1)$,

$$
\begin{aligned}
& c_{1 i}\left(s^{t}\right)=C_{1}^{s}\left(s^{t}\right), c_{2 i}\left(s^{t}\right)=C_{2}^{s}\left(s^{t}\right) ; g_{i}\left(s^{t}\right)=G^{s}\left(s^{t}\right) ; n_{i}\left(s^{t}\right)=N^{s}\left(s^{t}\right) \text { for all } i \in[0, \alpha] ; \\
& c_{1 i}\left(s^{t}\right)=C_{1}^{f}\left(s^{t}\right), c_{2 i}\left(s^{t}\right)=C_{2}^{f}\left(s^{t}\right) ; g_{i}\left(s^{t}\right)=G^{f}\left(s^{t}\right) ; n_{i}\left(s^{t}\right)=N^{f}\left(s^{t}\right) \text { for all } i \in(\alpha, 1] .
\end{aligned}
$$

\section{Proof:}

(a) The price-setting condition of the monopolists (22) implies that all firms set the same price. The demand functions (11), (12), and (20) imply that quantities will be the same across goods for all $i \in[0,1]$ and equal to the aggregate.

(b) Conditions (22) and (25) imply that all flexible price firms set a common price and so do all sticky price firms. Therefore, the demand functions imply that the quantities will be the

same across flexible price firms and across sticky price firms, where $C_{j}^{f}\left(s^{t}\right), C_{j}^{s}\left(s^{t}\right), j=1,2, G^{f}\left(s^{t}\right)$, 
and $G^{s}\left(s^{t}\right)$ denote those common values of private and public consumption of the goods produced by the flexible and sticky price firms, respectively.

In the flexible price economies (part a of lemma 1), since all firms set the same price, the quantities are the same, so that one unit of labor applied to the production of any of the intermediate goods has the same marginal impact on the production of the final good. This is the condition that guarantees productive efficiency, meaning that production takes place along the production possibilities frontier.

When there are sticky price firms as well (part b), there may be equilibria in which the production of the flexible price firms is different from the production of the sticky price firms. In such cases, the aggregates are in the interior of the production possibilities set. To see this, notice that if we add up the market-clearing conditions for each good $i,(27)$, and use the demand functions (11), (12), and (20), as well as resource constraints (28), then we obtain

$$
\left[C_{1}\left(s^{t}\right)+C_{2}\left(s^{t}\right)+G\left(s^{t}\right)\right]\left[\alpha \frac{C_{j}^{s}\left(s^{t}\right)}{C_{j}\left(s^{t}\right)}+(1-\alpha) \frac{C_{j}^{f}\left(s^{t}\right)}{C_{j}\left(s^{t}\right)}\right]=A\left(s^{t}\right) N\left(s^{t}\right), j=1,2
$$

where

$$
C_{j}\left(s^{t}\right)=\left[\alpha C_{j}^{s}\left(s^{t}\right)^{\frac{\theta-1}{\theta}}+(1-\alpha) C_{j}^{f}\left(s^{t}\right)^{\frac{\theta-1}{\theta}}\right]^{\frac{\theta}{\theta-1}}, j=1,2
$$

It can be shown that $\alpha \frac{C_{j}^{s}\left(s^{t}\right)}{C_{j}\left(s^{t}\right)}+(1-\alpha) \frac{C_{j}^{f}\left(s^{t}\right)}{C_{j}\left(s^{t}\right)}>1$ whenever $C_{j}^{s}\left(s^{t}\right) \neq C_{j}^{f}\left(s^{t}\right), j=1,2$. When this is the case, production is inefficient.

If, in equilibrium, the prices of the flexible and sticky price firms were the same, then $C_{j}^{s}\left(s^{t}\right)=C_{j}^{f}\left(s^{t}\right), j=1,2$. In this case, as in the flexible price case, production would be along the 
production possibilities frontier described by

$$
C_{1}\left(s^{t}\right)+C_{2}\left(s^{t}\right)+G\left(s^{t}\right)=A\left(s^{t}\right) N\left(s^{t}\right) .
$$

\section{Allocations, prices and policies under flexible prices}

We now characterize the set of implementable allocations under flexible prices. It turns out that the set of implementable allocations is the same as in Lucas and Stokey (1983). With the policy instruments that we consider, there are multiple ways to decentralize a given allocation in that set. We show that it is always possible to decentralize an allocation with constant producer prices. This result will be instrumental in proving a major result in the article, namely, that every allocation under flexible prices can be implemented under sticky prices.

In the following proposition, we characterize the set of implementable allocations, prices and policies under flexible prices.

Proposition 1. (1) Under flexible prices, the set of implementable allocations for the consumption goods and labor, $\left\{C_{1}\left(s^{t}\right), C_{2}\left(s^{t}\right), N\left(s^{t}\right)\right\}$, is characterized by the implementability conditions

$$
\begin{gathered}
E_{0} \sum_{t=0}^{\infty} \beta^{t}\left[u_{C_{1}}\left(s^{t}\right) C_{1}\left(s^{t}\right)+u_{C_{2}}\left(s^{t}\right) C_{2}\left(s^{t}\right)+u_{N}\left(s^{t}\right) N\left(s^{t}\right)\right]=0, \\
u_{C_{1}}\left(s^{t}\right) \geq u_{C_{2}}\left(s^{t}\right),
\end{gathered}
$$

and the feasibility conditions

$$
C_{1}\left(s^{t}\right)+C_{2}\left(s^{t}\right)+G\left(s^{t}\right)=A\left(s^{t}\right) N\left(s^{t}\right) .
$$


(2) Each allocation $\left\{C_{1}\left(s^{t}\right), C_{2}\left(s^{t}\right), N\left(s^{t}\right)\right\}$ is implemented with a unique path for

$$
\left\{R\left(s^{t}\right), \frac{\left(1+\tau^{c}\left(s^{t}\right)\right)}{\left(1-\tau^{n}\left(s^{t}\right)\right)}, \frac{W\left(s^{t}\right)}{p_{f}\left(s^{t}\right)}\right\}_{t=0}^{\infty} .
$$

Given $P^{c}\left(s_{0}\right)$, there is a unique solution for $\left\{P^{c}\left(s^{t}\right)=\left[1+\tau^{c}\left(s^{t}\right)\right] p_{f}\left(s^{t}\right)\right\}_{t=0}^{\infty}$. If the cash-in-advance constraint holds with equality in all periods and states, then given $P^{c}\left(s_{0}\right)$, there is also a unique solution for $\left\{\bar{B}^{g}\left(s^{t}\right), M\left(s^{t}\right)\right\}_{t=0}^{\infty}$.

Proof: In order to show part 1, we need to show that conditions (33), (34), and (35) are necessary and sufficient for an equilibrium allocation $\left\{C_{1}\left(s^{t}\right), C_{2}\left(s^{t}\right), N\left(s^{t}\right)\right\}_{t=0}^{\infty}$. That they are necessary conditions is straightforward. Condition (33) is (19) for $t=0$; condition (34) is the restriction that nominal interest rates be nonnegative, and we know from lemma 1 that consumption and labor input are the same for every good $i \in[0,1]$, so that the resource constraints $(27)$ and (28) imply (35). We need to show that there are prices, policies, and allocations other than $\left\{C_{1}\left(s^{t}\right), C_{2}\left(s^{t}\right), N\left(s^{t}\right)\right\}_{t=0}^{\infty}$ that satisfy the remaining equilibrium conditions. In doing so, we will also be able to prove part 2 of the proposition.

The household marginal conditions on the choice of cash and credit goods, (13), determine uniquely the nominal interest rates $\left\{R\left(s^{t}\right)\right\}_{t=0}^{\infty}$, which are nonnegative because of (34). Given $P^{c}\left(s_{0}\right)$, conditions (19) and (16) for $t \geq 1$, repeated here,

$$
\begin{aligned}
& E_{t} \sum_{r=t}^{\infty} \beta^{r-t}\left[u_{C_{1}}\left(s^{r}\right) C_{1}\left(s^{r}\right)+u_{C_{2}}\left(s^{r}\right) C_{2}\left(s^{r}\right)+u_{N}\left(s^{r}\right) N\left(s^{r}\right)\right] \\
& \quad=u_{C_{1}}\left(s^{t}\right) \frac{\mathbb{W}\left(s^{t}\right)}{P^{c}\left(s^{t}\right)}, t \geq 1
\end{aligned}
$$


where

$$
\begin{aligned}
\mathbb{W}\left(s^{t}\right)= & M\left(s^{t-1}\right)+R\left(s^{t-1}\right) \bar{B}\left(s^{t-1}\right) \\
& -P^{c}\left(s^{t-1}\right)\left[C_{1}\left(s^{t-1}\right)+C_{2}\left(s^{t-1}\right)+\frac{u_{N}\left(s^{t-1}\right)}{u_{C_{2}}\left(s^{t-1}\right)} N\left(s^{t-1}\right)\right],
\end{aligned}
$$

and

$$
\frac{u_{C_{1}}\left(s^{t-1}\right)}{P^{c}\left(s^{t-1}\right)}=\beta R\left(s^{t-1}\right) E_{t-1}\left[\frac{u_{C_{1}}\left(s^{t}\right)}{P^{c}\left(s^{t}\right)}\right], t \geq 1,
$$

determine recursively $P^{c}\left(s^{t}\right)$ and $M\left(s^{t-1}\right)+R\left(s^{t-1}\right) \bar{B}\left(s^{t-1}\right)$. Let $\Phi_{t}$ be the number of states in period $t$, with $\Phi_{0}=1$. For any $t \geq 1$, given the values for $P^{c}\left(s^{t-1}\right)$, there are $\Phi_{t-1}$ intertemporal constraints (37) and $\Phi_{t}$ budget constraints (36) to determine $\Phi_{t}+\Phi_{t-1}$ variables, the consumer price levels, and the state-noncontingent nominal asset levels, $P^{c}\left(s^{t}\right)$ and $M\left(s^{t-1}\right)+R\left(s^{t-1}\right) \bar{B}\left(s^{t-1}\right)$. This shows that given $P^{c}\left(s_{0}\right)$, the paths for $\left\{P^{c}\left(s^{t}\right), M\left(s^{t}\right)+R\left(s^{t}\right) \bar{B}\left(s^{t}\right)\right\}_{t=0}^{\infty}$ are uniquely determined. If the cash-in-advance constraint, $(9)$, holds with equality, then given $P^{c}\left(s_{0}\right)$, the money supply is uniquely determined. It follows that the supply of noncontingent debt is also uniquely determined.

The price-setting equations, (22), determine uniquely the real wages $\left\{W\left(s^{t}\right) / p_{f}\left(s^{t}\right)\right\}_{t=0}^{\infty}$. From the consumer price-level condition, (10), we know that $P^{c}\left(s^{t}\right)=\left[1+\tau^{c}\left(s^{t}\right)\right] p_{f}\left(s^{t}\right)$. The household intratemporal conditions, (14), given $\left\{W\left(s^{t}\right) / p_{f}\left(s^{t}\right)\right\}_{t=0}^{\infty}$, determine, also uniquely, the proportionate tax distortions, $\left\{\left[1+\tau^{c}\left(s^{t}\right)\right] /\left[1-\tau^{n}\left(s^{t}\right)\right]\right\}_{t=0}^{\infty}$. Finally, the prices of the statecontingent debt, $Q\left(s^{t+1} \mid s^{t}\right)$, are given by (15).

As mentioned above, the set of implementable allocations is the same here as in Lucas and Stokey (1983) and Chari et al. (1991), where firms are assumed to be competitive. The revenue 
from the full taxation of profits is the revenue needed to finance the implicit subsidy to labor needed to eliminate the monopoly distortion. This implicit subsidy means that the taxes on labor are lower than they would be without it. With such taxes and implicit subsidies, the optimal allocation in this economy with imperfect competition equals that in an otherwise identical economy with perfect competition. ${ }^{7}$

Part 2 of proposition 1 implies that there are multiple fiscal policies consistent with each implementable allocation. One of those policies supports producer prices, $p_{f}\left(s^{t}\right)$, which are constant over time. We state this result in the following corollary.

Corollary 1. Each allocation in the set of implementable allocations in proposition 1 can be implemented with policies such that the producer prices are constant over time and equal to an arbitrary level, $p_{f}\left(s^{t}\right)=\bar{P}$.

Proof: Consider an implementable allocation $\left\{C_{1}\left(s^{t}\right), C_{2}\left(s^{t}\right), N\left(s^{t}\right)\right\}_{t=0}^{\infty}$ in the set defined by the implementability and feasibility conditions, (33), (34) and (35). From part 2 of proposition 1 , we know that, given $P^{c}\left(s_{0}\right)$, the four variables $\tau^{c}\left(s^{t}\right), \tau^{n}\left(s^{t}\right), p_{f}\left(s^{t}\right)$, and $W\left(s^{t}\right)$ are restricted by only three restrictions, the values of $\left[1+\tau^{c}\left(s^{t}\right)\right] /\left[1-\tau^{n}\left(s^{t}\right)\right],\left[1+\tau^{c}\left(s^{t}\right)\right] p_{f}\left(s^{t}\right)$, and $W\left(s^{t}\right) / p_{f}\left(s^{t}\right)$, for each period and state. The path for one of the variables is unrestricted and therefore can be set equal to an arbitrary sequence, for example, $p_{f}\left(s^{t}\right)=\bar{P}$ for all $s^{t}$.

\section{Allocations, prices, and policies under sticky prices}

In comparing economies with and without sticky prices, we maintain the same objective function for the government. Thus, the relevant object to compare is the set of implementable allocations in each case. Under flexible prices, as shown in proposition 1, the set of implementable allocations 
can be characterized as restrictions on allocations only, independently of prices and taxes. Under sticky prices, such characterization is not possible, and instead the implementable set is defined by all the equilibrium conditions stated in Section II. Because of this, we find it convenient to take an indirect route in proving the main results.

We first use corollary 1 to show that the set of flexible price allocations is contained in the set of sticky price allocations for any value of $\alpha$ (proposition 2, part 1). We also show that any allocation that is both a flexible price allocation and a sticky price allocation can be implemented by the same policy (proposition 2, part 2).

We then consider an artificial Ramsey problem designed to make our proofs simple. This Ramsey problem is defined over the set of all allocations that can be obtained with any relative prices of the differentiated goods. This large set clearly contains the set of sticky price allocations, for any value of $\alpha$. We then show that the optimal allocation in the larger set is a flexible price allocation. It follows that the optimal allocation is the same under sticky prices as under flexible prices (proposition 3).

Proposition 2. (1) The set of implementable allocations under flexible prices is a subset of the implementable set under sticky prices for any degree of price stickiness, $0 \leq \alpha<1$.

(2) Each allocation in that common set can be implemented with policies that are independent of the degree of price stickiness, $0 \leq \alpha<1$.

Proof: Let $p_{f}\left(s^{t}\right)=p_{-1}, t \geq 0$. From (26), we know that the prices of the sticky and flexible price firms coincide, $p_{s}\left(s^{t-1}\right)=p_{f}\left(s^{t}\right)=p_{-1}, t \geq 1$. The equilibrium conditions, irrespective of $\alpha>0$, collapse to the ones under flexible prices, in addition to the constraint that the producer price level, $p_{f}\left(s^{t}\right)$, is constant over time. With corollary 1 , there are policies under 
flexible prices that implement each allocation with constant producer prices equal to $\bar{P}=p_{-1}$. Those policies clearly do not depend on the degree of price stickiness, $0 \leq \alpha<1$.

We could have proven the proposition without imposing that the producer price level be constant over time. The producer price level could, for instance, grow at a constant or forecastable rate. Indeed, we could have stated corollary 1 in a weaker form and shown that there are policies under flexible prices such that the producer price level does not move with contemporaneous information instead of being constant. We have stated the corollary in this form because it will be used to show that the allocations under flexible prices can be implemented under sticky prices, also when the assumptions on price setting are more restrictive, as in the case of staggered prices without indexation.

Let $\Omega^{f}$ be the set of implementable allocations under flexible prices, characterized in proposition 1 , and $\Omega^{s}(\alpha)$ be the set of allocations under sticky prices for $\alpha \in(0,1){ }^{8}$ Proposition 2, part 1 , then states that

$$
\Omega^{f} \subset \Omega^{s}(\alpha)
$$

It follows that a Ramsey government under sticky prices cannot do worse than a Ramsey government under flexible prices. We now show that it cannot do better either. ${ }^{9}$

As already mentioned, characterizing the set $\Omega^{s}(\alpha)$ is cumbersome. We consider a larger set $\Omega^{R}$ of allocations in which relative prices are not restricted, referred to as the relaxed set, which contains $\Omega^{s}(\alpha)$, so that we have

$$
\Omega^{f} \subset \Omega^{s}(\alpha) \subset \Omega^{R}
$$

We then show that the optimal allocation in $\Omega^{R}$ belongs to $\Omega^{f}$. This result obviously implies that the optimal allocation in all three sets is the same. 
We define the relaxed Ramsey problem as one in which the choice set is the relaxed set. ${ }^{10}$ By allowing for any configuration of relative prices across differentiated goods, we are considering allocations with very general configurations of equilibrium quantities across goods. As shown in Section II, when some relative prices are different from one, the aggregation of market-clearing conditions (27) is not as straightforward as in the case of flexible prices, where all the quantities of the differentiated goods are equal to the aggregate. It is possible, however, to obtain a relationship between aggregate demand and aggregate supply, analogous to (35), that depends on the relative prices. If we add up the market-clearing conditions for each good $i,(27)$, and use the demand functions (11), (12), and (20), as well as the resource constraints (28), we obtain these aggregate resource constraints: ${ }^{11}$

$$
\left[C_{1}\left(s^{t}\right)+C_{2}\left(s^{t}\right)+G\left(s^{t}\right)\right] \int_{0}^{1}\left[\frac{p_{i}^{c}\left(s^{t}\right)}{P^{c}\left(s^{t}\right)}\right]^{-\theta} d i=A\left(s^{t}\right) N\left(s^{t}\right) .
$$

The relaxed set is formally defined as the set of aggregate allocations $\left\{C_{1}\left(s^{t}\right), C_{2}\left(s^{t}\right), N\left(s^{t}\right)\right\}$ such that there exist consumer prices $\left\{p_{i}^{c}\left(s^{t}\right), P^{c}\left(s^{t}\right)\right\}$ that satisfy the following conditions: $(i)$ the resource constraints (38) hold; (ii) the aggregate consumer price level is consistent with the individual prices,

$$
P^{c}\left(s^{t}\right)=\left\{\int_{0}^{1}\left[p_{i}^{c}\left(s^{t}\right)\right]^{1-\theta} d i\right\}^{\frac{1}{1-\theta}}
$$

(iii) the implementability constraint (33) holds; and (iv) the nonnegativity constraint on nominal interest rates (34) is satisfied.

We then have the following proposition.

Proposition 3. The Ramsey allocation under sticky prices is the same as the Ramsey allo- 
cation under flexible prices, for any degree of price rigidity $0 \leq \alpha<1$.

Proof: Consider the problem of choosing a sequence of allocations $\left\{C_{1}\left(s^{t}\right), C_{2}\left(s^{t}\right), N\left(s^{t}\right)\right\}_{t=0}^{\infty}$ and relative prices $\left\{p_{i}^{c}\left(s^{t}\right) / P^{c}\left(s^{t}\right)\right\}_{t=0}^{\infty}$ for $i \in[0,1]$ that maximizes utility in the relaxed set characterized by the conditions (33), (34), (38), and (39). We first show that the optimal allocation in the relaxed set belongs to the flexible price set. Since $\theta>1$, the term in the resource constraints $(38)$,

$$
D\left(s^{t}\right) \equiv \int_{0}^{1}\left[\frac{p_{i}^{c}\left(s^{t}\right)}{P^{c}\left(s^{t}\right)}\right]^{-\theta} d i \geq 1
$$

is minimized subject to (39) when $p_{i}^{c}\left(s^{t}\right)=P^{c}\left(s^{t}\right)$, so that $D\left(s^{t}\right)=1$. Otherwise $D\left(s^{t}\right)>1$. The resource constraints become the ones under flexible prices. Since the other constraints are common to the flexible and relaxed sets, the planner faces the same constraints in the two problems, and the optimal solutions coincide. Thus, the Ramsey allocation under flexible prices maximizes welfare in the set of allocations in $\Omega^{R}$.

The set of implementable allocations under sticky prices is contained in the relaxed set, $\Omega^{s}(\alpha) \subset \Omega^{R}$. Indeed, the allocations under sticky prices must satisfy the conditions characterizing the relaxed set. The implementability condition (33) was derived using the household conditions that are the same under flexible and sticky prices. The condition that the nominal interest rate must be positive, (34), must also be satisfied under sticky prices, and so must the resource constraints (38), as well as the restrictions on the relative prices $(39) .{ }^{12}$

From proposition 2, we know that $\Omega^{f} \subset \Omega^{s}(\alpha)$. Since $\Omega^{f} \subset \Omega^{s}(\alpha) \subset \Omega^{R}$ for any value of $\alpha$, then the optimal allocation under flexible prices also maximizes welfare in the set of sticky price allocations, $\Omega^{s}(\alpha)$, for any value of $\alpha$.

We next state a proposition on the irrelevance of sticky prices for the policies that implement 
the Ramsey allocation.

Proposition 4. The Ramsey allocation, common to flexible and sticky price economies, can be implemented by policies that do not depend on the degree of price rigidity, for $0 \leq \alpha<1$. Under flexible prices, the set of policies that implement the Ramsey allocation is a larger set including policies that would not implement the Ramsey allocation under sticky prices, for $0<\alpha<1$.

Proof: The first statement in the proposition is a direct implication of the previous two propositions. For $0<\alpha<1$, the Ramsey allocation can be implemented with a policy that is associated with a constant producer price level. That policy obviously also implements the Ramsey allocation under flexible prices. However, under flexible prices, there are other policies, where the price level moves with contemporaneous information, that implement the Ramsey allocation. For those other policies, the allocation would violate productive efficiency if firms were constrained in the setting of prices.

Nonbenevolent government So far, we have followed the Ramsey tradition in assuming that the government is benevolent and aims at maximizing the utility function of the households. However, our results are more general, as the proof of proposition 3 makes clear.

Assume now that government preferences on the final goods are given by

$$
E_{0} \sum_{t=0}^{\infty} \beta^{t} F\left(C_{1}\left(s^{t}\right), C_{2}\left(s^{t}\right), N\left(s^{t}\right)\right),
$$

where $F$ is increasing in aggregate consumption of both goods and decreasing in aggregate labor and differentiable. The arguments in this section follow through directly.

The optimal problem can be solved in two steps. The first step is choosing relative prices 
to minimize the resource cost due to productive inefficiency. The solution is the set of productiveefficient allocations, as under flexible prices. This step is independent of the objective function as long as it is a function of the aggregates. The second step is the maximization of the objective function subject to the implementability conditions and the resource constraints under flexible prices. This second step obviously depends on the objective function.

\section{Interpreting the results: Optimality of zero taxation of intermediate goods}

In this section, we relate our results to the work of Diamond and Mirrlees (1971) on the optimal taxation of intermediate goods. To make this connection, we first interpret the individual goods as intermediate inputs in the production of aggregate consumption. We then allow for different taxes on those goods. In particular, let $\tau_{i}^{c}\left(s^{t}\right)$ be the tax levied on good $i$ in state $s^{t}$, so that the price of $\operatorname{good} i$ gross of taxes is $p_{i}^{c}\left(s^{t}\right)=\left[1+\tau_{i}^{c}\left(s^{t}\right)\right] p_{i}\left(s^{t}\right)$.

In our benchmark economy without good-specific taxes, sticky prices can distort the relative prices across goods. The sticky price firms, namely, those with $i \leq \alpha$, can charge a price different from that of the flexible price firms, with $i>\alpha$. Under flexible prices, we can replicate these

allocations with one tax, $\tau_{s}^{c}\left(s^{t}\right)$, for the firms with $i \leq \alpha$, and another, $\tau_{f}^{c}\left(s^{t}\right)$, for the remaining firms.

Our result that the optimal allocations under flexible and sticky prices coincide is equivalent to the result in this alternative economy that it is optimal to tax all goods at the same rate. This latter result is in turn a special case of Diamond and Mirrlees (1971).

In general, if we were to consider good-specific taxes under flexible prices and no restrictions were imposed on those taxes, then the set of implementable allocations would be the relaxed set, $\Omega^{R}$. If those same taxes were available under sticky prices, then the set of implementable allocations 
would also be the relaxed set. We show both these results in the Appendix. As we showed in proposition 3, the optimal allocation in the relaxed set is in the set under flexible prices without good-specific taxes, $\Omega^{f}$. The optimality of a constant tax across goods, $\tau_{i}^{c}\left(s^{t}\right)=\tau^{c}\left(s^{t}\right)$ for all $i$, and our equivalence results are applications of the same principle that productive efficiency is optimal, under quite general conditions, even in a distorted second-best world, as shown by Diamond and Mirrlees (1971).

The good-specific taxes are redundant instruments, in the sense that a Ramsey government would not use them as part of the optimal policy. Similarly, when prices are sticky, a Ramsey government that is not allowed to use good-specific taxes can implement allocations that are not productive-efficient, but will choose not to. Policy in a sticky price environment partially completes the set of instruments, in the sense made explicit in Chari and Kehoe (1999). However, the extra instrument provided by price stickiness is redundant, in the same way that the good-specific taxes are.

\section{Robustness}

\section{A. Alternative price-setting restrictions}

We have established the irrelevance of the degree of price stickiness for the optimal choice of allocations and policies in a model with prices set one period in advance. This particular form of price stickiness has obvious limitations for the lack of persistence of a monetary policy shock. In this section, we argue that our results are robust to the consideration of alternative forms of price-setting restrictions.

Consider, for example, introducing into our model the price-setting restrictions suggested by Calvo (1983). ${ }^{13}$ Calvo assumes that firms are able to revise prices with probability $\gamma>0$. Since 
there is a continuum of firms, the probability $\gamma$ is also the share of firms that are able to revise the price in a given period. These price-setting restrictions introduce heterogeneity across firms, given by the period in which they get the chance to optimally decide on the price. This is the only asymmetry across firms.

Suppose that the economy started from a steady state in which all the firms charged the same price, $p_{-1}$. In any time period $t$, the $\gamma$ fraction of firms that get the chance to change the price will choose the same price, since technologies, demand functions, and information sets are the same. As time passes, the heterogeneity may increase. In fact, a result similar to lemma 1 can be stated in which in each period $t$ there can be, at most, as many different equilibrium prices as the number of periods. This does not imply that, in period $t$, there will always be $t$ different prices. The policy may be such that the firms that are able to change prices choose to set the same price as the firms that are restricted not to change them.

Indeed, if the policy were the one described in corollary 1 , such that under flexible prices the producer price level would be constant and equal to the exogenous initial price, $p_{-1}$, then all the firms would want to set that same price when given the chance. The price-setting restrictions would not be binding, and therefore, under staggered prices, it would be possible to implement the flexible price allocations, so that

$$
\Omega^{f} \subset \Omega^{S t a g}(\gamma)
$$

where $\Omega^{\text {Stag }}$ is the set of implementable allocations under staggered prices.

As in the proof of proposition 3, for the case with prices set in advance, here it can be shown that $\Omega^{\operatorname{Stag}}(\gamma)$ is contained in the relaxed set, 


$$
\Omega^{S t a g}(\gamma) \subset \Omega^{R}
$$

for any $\gamma \cdot{ }^{14}$ To see this, notice, again, that the implementability condition (33) was derived using the conditions for the households that are the same under flexible and sticky prices, whether these are set in advance or staggered. The condition that the nominal interest rate must be positive, (34), must also be satisfied under staggered prices, and so must be the resource constraints (38), as well as the restrictions on the relative prices (39).

Since, as shown in the proof of proposition 3, the optimal allocation in $\Omega^{R}$ is in $\Omega^{f}$ and since $\Omega^{f} \subset \Omega^{\text {Stag }}(\gamma) \subset \Omega^{R}$, it must be that the optimal allocation in $\Omega^{\text {Stag }}(\gamma)$ is in $\Omega^{f}$. Thus, the result in proposition 3, that the optimal allocations coincide under flexible and sticky prices, for any degree of price rigidity, follows through. The optimal allocation under staggered prices is implemented with a policy that induces a constant producer price level, and therefore, the optimal policy is also independent of the price rigidity.

These results under Calvo (1983) staggered prices obviously generalize to other forms of price setting, such as the staggered prices in Taylor (1980), the costly price adjustments in Rotemberg (1982), and the state-dependent pricing in Dotsey, King, and Wolman (1999).

We have assumed that the firms that are not able to optimally choose prices must keep them constant, not even being able to index them to some average inflation rate. This is a strong form of price rigidity. If the Calvo firms that cannot optimally choose prices were able to change them according to the long-run inflation rate, then the equivalence results would hold for policies that have producer prices grow at that same rate. Whether optimal producer prices are constant or can have a trend has implications for the tax policies supporting the Ramsey allocation, which 
we discuss in Section VI.B.

If the source of nominal rigidity were on the setting of wages, rather than prices, then the arguments in this article would follow through as well. The key point is that, in a world with flexible prices and wages, the set of implementable allocations can be decentralized with policies that keep wages constant over time. This is an implication of part 2 of proposition 1, which establishes that in a flexible environment, one of the paths for the price level, the nominal wage, or one of the taxes, on consumption or labor income, is not pinned down. This implies that each allocation can be implemented with a policy that sets the nominal wage equal to some exogenous constant value, and therefore, if restrictions on the setting of wages were to be imposed, they would not be binding. The optimality result is also straightforward.

\section{B. Restrictions on fiscal policy instruments and optimal policies}

In order to obtain the equivalence results in this article, it is crucial that both consumption and labor income taxes are used. With only one tax, the optimal policy, and corresponding allocation, would depend on the extent of the price rigidity, as in the related literature by Benigno and Woodford (2003), Schmitt-Grohé and Uribe (2004), and Siu (2004).

The two taxes, on consumption and labor income, are needed to obtain the first instrumental result, that the set of implementable allocations under flexible prices is also implementable under sticky prices for any degree and type of price stickiness, including staggered prices as in Calvo (1983). In order to implement productive-efficient allocations, as under flexible prices, with Calvo price setting, producer prices must be constant over time. It turns out, as we have shown in the proof of corollary 1, that the policy that implements each allocation with a constant producer price level is unique. This means that all the policy instruments are necessary to obtain the result; there 
are no redundant policy instruments.

To clarify this point, suppose that one of the taxes, say the consumption tax, were set to zero in every time period and state. Under flexible prices, because producer price volatility is costless, it would still be possible to implement the same allocations, as in Chari et al. (1991). The set of implementable allocations would still be characterized by the conditions in proposition 1 , the implementability condition, the condition that the interest rate be positive, and the feasibility conditions. ${ }^{15}$ Instead, under sticky prices - in particular under staggered prices - it would no longer be possible to implement that whole set. With constant producer prices, there would not be enough policy variables to satisfy all the remaining equilibrium conditions. In particular, there would be no instruments with which to satisfy the intertemporal conditions (16) and the budget constraints (19), so that these would have to be added as additional constraints to the Ramsey problem.

When prices are sticky, the producer price level must be constant over time and across states in order to ensure productive efficiency; however, the price gross of consumption taxes must vary across states in order to satisfy the intertemporal conditions and replicate real state-contingent debt. Without consumption taxes, these objectives are just not compatible. The optimal allocation under sticky prices does not coincide with the optimal allocation under flexible prices and gives lower welfare, and the extent of the price rigidity matters for the conduct of policy.

This is the case in Schmitt-Grohé and Uribe (2004) and Siu (2004), which consider environments similar to the one we analyze, but assume that consumption taxes are not available. In their numerical examples calibrated to U.S. postwar data, the costs of price volatility by far outweigh the gains. Productive efficiency is a dominant force, so that the optimal policy induces a price level that is nearly constant. As a result, the nominal interest rate is greater than zero and fluctuates, and real debt is not state-contingent. 
Benigno and Woodford (2003) also study a similar economy but impose that labor income taxes are set to zero. For them, consumption taxes are necessary to satisfy the marginal conditions between labor and consumption of the credit good, so that, again, there are no policy instruments with which to satisfy both the intertemporal conditions and the budget constraints, (16) and (19). As in Siu and Schmitt-Grohé and Uribe, the price stickiness matters for the conduct of fiscal and monetary policy.

Once we consider the policy instruments in those three studies, their results are fundamentally changed, and we obtain our equivalence results. The optimal policy induces producer price stability, so that the allocations are productive-efficient. The degree of rigidity is irrelevant for the optimal allocations, and the same policy can implement the optimal allocation irrespective of the price rigidity.

Optimal policies An intuitive discussion on how the policy instruments implement the optimal allocation is as follows: the intratemporal conditions between cash and credit goods, and between the credit good and leisure determine, respectively, the nominal interest rate and the labor income tax, given a path for consumption taxes. The quantity of money must be chosen so as to satisfy the cash-in-advance constraint with a constant producer price level, also given a path for consumption taxes. Given that the producer price level is constant, the budget constraints and the intertemporal conditions determine the movement of consumption tax across states as well as the stock of noncontingent nominal debt. The conditional volatility of the consumption tax plays the role of the ex post volatility of the price level in replicating real state-contingent debt in Chari et al. (1991). The conditional average of the consumption tax allows the government to break the equality between real and nominal interest rates that would otherwise be implied by perfect price 
stability.

In the monetary model with cash and credit goods, the optimal nominal interest rate is zero when preferences are separable in leisure and homothetic in the consumption goods. ${ }^{16}$ If the Friedman rule of a zero nominal interest rate is optimal, and firms keep prices constant over time, then it must be the case that consumption taxes decrease over time at the real interest rate. The expression $1+\tau^{c}$, for the consumption tax, will converge to zero from above, and so will $1-\tau^{n}$, for the labor income tax. Neither expression will become negative.

In the previous subsection on alternative price-setting restrictions, we argued that a constant producer price level was a necessary condition to neutralize price-setting restrictions without indexation, but that that was no longer the case if firms could index prices to a constant inflation rate. In that case, productive inefficiencies are eliminated when producer prices grow at that constant rate. For that weaker form of price rigidity, the optimal consumption taxes would still have to move with the real interest rate but would not necessarily have a trend. If average producer price inflation were equal to minus the long-run real interest rate, the consumption taxes would on average be constant.

The volatility of consumption taxes aimed at replicating real state-contingent debt would obviously not be a feature of optimal policy if state-contingent debt could be issued or if there were alternative ways of replicating state-contingent debt. For instance, real state-contingent debt can be replicated with government debt of longer maturities, as shown by Angeletos (2002) and Buera and Nicolini (2004). An alternative way to replicate state-contingent debt is to allow for state-contingent taxes on interest earnings. If those taxes were available, then the volatility of consumption taxes could be replaced by the volatility of those taxes.

Even with state-contingent debt, in general, it is still necessary to use both consumption 
and labor income taxes to obtain the equivalence results. The reason is that with constant producer prices (or producer prices growing at a constant rate), consumption taxes must satisfy the Fisher equation, so that a desired path for the real interest rate can be consistent with a desired path for the nominal interest rate. In the particular environments of Benigno and Woodford (2003) and Siu (2004), however, with state-contingent debt there would be no need for consumption taxes to obtain the results. In Benigno and Woodford's work, because the economy is cashless, the nominal interest rate does not distort allocations, and therefore state-contingent debt is all that is needed to obtain the equivalence results. In Siu's work, because prices are set one period in advance, productive efficiency is guaranteed with prices that move with lagged information. Firms that set prices for tomorrow can set inflation equal to minus the real interest rate and implement the Friedman rule with no costs in terms of productive efficiency.

\section{Concluding remarks}

A major question of recent renewed interest is how we should think differently about conducting monetary policy if we move from a world of flexible prices to a world with sticky prices. A contribution of this article is to show that the answer to this question depends critically on the available set of fiscal policy instruments.

In models in which fiscal policy is restricted, such as Schmitt-Grohé and Uribe (2004) and Siu (2004), which consider only labor income taxes, or Benigno and Woodford (2003), which allows for only consumption taxes, the nominal rigidity matters for the conduct of policy. In those models, both optimal allocations and policies are affected by the degree and type of price rigidity. Instead, in our setup, where we assume that there are both consumption and labor income taxes, the optimal allocation and the policy that implements it do not depend on the nominal rigidity. 
The basic intuition for our result is the following. In most models with sticky prices, the price-setting restrictions affect different firms differently. For example, in Calvo (1983), only a fraction of firms can change prices in any period. Whenever policy exploits the nonneutrality resulting from the price-setting restrictions, there will be relative price distortions that can be interpreted as a productive inefficiency. As long as there are taxes on the final goods, this productive inefficiency will be undesirable, even in a distorted, second-best, environment. This result recalls the well-known result in the public finance literature due to Diamond and Mirrlees (1971). In Diamond and Mirrlees's article, as long as consumption taxes on the final goods are available, it is not optimal to tax intermediate goods. We are able to establish a similar result, that in our second-best world, it is optimal to eliminate distortions in production. That is achieved by pursuing producer price stability, therefore neutralizing the effects of price-setting restrictions, whatever they may be.

We make our point in a simple, and somewhat extreme, form. Given our assumptions on the available government debt instruments - just one-period nominal noncontingent debtconsumption taxes play the role of replicating real state-contingent debt, and as a result, both optimal consumption and labor income taxes may appear to be very volatile. This volatility can be mitigated and possibly eliminated if, instead, other policy instruments are considered, such as government bonds of different maturities or state-contingent taxes on interest rates. Similarly, we assume extreme forms of price stickiness, with long-run nonneutralities, where firms are restricted from changing prices at some constant rate. As a result, in order to eliminate productive inefficiencies, there can be no trend in producer prices. If the optimal nominal interest rate is zero, as the Friedman rule prescribes, then there will be a trend in optimal consumption and labor income taxes. This will not be the case if firms can index prices. 
We consider, as does most of this literature, models with sticky prices in which the degree of price stickiness is exogenous. This is not a natural assumption when computing the optimal policies because the price-setting restrictions will in general depend on the policy. Considering this, however, would be irrelevant if, as we show, policy does not depend on those restrictions.

A final remark: We have considered a model with a representative household and made the standard Ramsey assumptions that there are no lump-sum taxes and that leisure cannot be taxed. We could have instead considered a model with heterogeneous agents that differ in their unobservable skill levels, as in Costa and Werning (2002) after Mirrlees (1971). We would expect the same results in that alternative setup, that production distortions are inefficient and that price stability is optimal.

\section{REFERENCES}

[1] Adão, Bernardino, Isabel Correia and Pedro Teles. 2003. "Gaps and Triangles." Rev. Econ. Studies 70 (October): 699-713.

[2] Angeletos, George-Marios. 2002. "Fiscal Policy with Non-Contingent Debt and the Optimal Maturity Structure." Q.J.E. 117 (August): 1105-1131.

[3] Benigno, Pierpaolo and Michael Woodford. 2004. "Optimal Monetary and Fiscal Policy: A Linear Quadratic Approach." In NBER Macroeconomics Annual 2003, vol. 18, edited by Mark Gertler and Kenneth Rogoff. Cambridge, MA: MIT Press.

[4] Buera, Francisco and Juan Pablo Nicolini. 2004. "Optimal Maturity of Government Debt without State Contingent Bonds." J. Monetary Econ. 51 (April): 531-554. 
[5] Calvo, Guillermo. 1983. "Staggered Prices in a Utility-Maximizing Framework." J. Monetary Econ. 12 (September): 383-398.

[6] Chari, V. V., Lawrence Christiano and Patrick Kehoe. 1991. "Optimal Fiscal and Monetary Policy: Some Recent Results." J. Money, Credit, and Banking 23 (August): 519-539.

[7] Chari, V. V. and Patrick Kehoe. 1999. "Optimal Fiscal and Monetary Policy." In Handbook of Macroeconomics, vol. 1C, edited by John Taylor and Michael Woodford. Amsterdam: NorthHolland.

[8] Clarida, Richard, Jordi Gali, and Mark Gertler. 1999. "The Science of Monetary Policy: A New Keynesian Perspective." J. Econ. Literature 37 (December): 1661-1707.

[9] Correia, Isabel, Juan Pablo Nicolini and Pedro Teles. 2002. "Optimal Fiscal and Monetary Policy: Equivalence Results." Fed. Reserve Bank Chicago WP-02-16 (November).

[10] Costa, Carlos da and Ivan Werning. 2002. "On the Optimality of the Friedman Rule with Heterogeneous Agents and Nonlinear Income Taxation." Manuscript, MIT.

[11] Diamond, Peter A. and James A. Mirrlees. 1971. "Optimal Taxation and Public Production." A.E.R. 61 (March): 8-27; (June): 261-268.

[12] Dotsey, Michael, Robert G. King and Alexander Wolman. 1999. "State Dependent Pricing and the General Equilibrium Dynamics of Money and Output." Q.J.E. 114 (May): 655-690.

[13] Ireland, Peter. 1996. "The Role of Countercyclical Monetary Policy." J.P.E. 104 (August): 704-723. 
[14] Kahn, Aubik, Robert G. King and Alexander L. Wolman. 2003. "Optimal Monetary Policy." Rev. Econ. Studies 70 (October): 825-860.

[15] Lucas, Robert E., Jr. and Nancy L. Stokey. 1983. "Optimal Fiscal and Monetary Policy in an Economy without Capital." J. Monetary Econ. 12 (1): 55-93.

[16] Mirrlees, James A. 1971. "An Exploration in the Theory of Income Taxation." Rev. Econ. Studies 38 (April): 75-208.

[17] Rotemberg, Julio J. 1982. "Sticky Prices in the United States." J.P.E. 90 (December): 11871211.

[18] Rotemberg, Julio J. and Michael Woodford. 1997. "An Optimization Based Framework for the Evaluation of Monetary Policy." In NBER Macroeconomics Annual 199\%, vol. 12, edited by Ben S. Bernanke and Julio J. Rotemberg. Cambridge, MA: MIT Press.

[19] Schmitt-Grohé, Stephanie and Martin Uribe. 2004. "Optimal Fiscal and Monetary Policy under Sticky Prices." J. Econ. Theory 114 (February): 198-230.

[20] Siu, Henry. 2004. "Optimal Fiscal and Monetary Policy with Sticky Prices." J. Monetary Econ. 51 (April): 575-607.

[21] Taylor, John. 1980. "Aggregate Dynamics and Staggered Contracts." J.P.E. 88 (February): 1-23.

[22] Woodford, Michael. 2003. Interest and Prices. Princeton, NJ: Princeton Univ. Press. 


\section{NOTES}

${ }^{1}$ In Khan et al. (2003), with staggered prices, there is also a trade-off between the money demand distortion and the distortion associated with sticky prices. In order to eliminate the latter, the price level would have to be constant over time, resulting in inefficient, positive, and varying nominal interest rates.

${ }^{2}$ Ireland (1996) considers a special case of preferences, technology, and shocks, in which the optimal allocations under flexible and sticky prices coincide.

${ }^{3}$ Even with our simplifying assumption that profits and initial wealth are fully taxed, there is still the need to raise revenues through distortionary taxes.

${ }^{4}$ Notice that the price of the credit good in state $s^{t}$, in units of money in period 0 , is $Q\left(s^{t} \mid s^{0}\right) \sum_{s^{t+1} \mid s^{t}} Q\left(s^{t+1} \mid s^{t}\right)=Q\left(s^{t} \mid s^{0}\right) / R\left(s^{t}\right)$. The reason is that, in Lucas timing, with the assets market in the beginning of the period, credit goods are paid in the beginning of the subsequent period. For this reason, the intertemporal condition (16) for the credit goods is $\frac{u_{C_{2}}\left(s^{t}\right)}{P^{c}\left(s^{t}\right)}=\beta E_{t}\left[R\left(s^{t+1}\right) \frac{u_{C_{1}}\left(s^{t+1}\right)}{P^{c}\left(s^{t+1}\right)}\right]$, with $R\left(s^{t+1}\right)$ the nominal interest rate between periods $t+1$ and $t+2$.

${ }^{5}$ See Correia, Nicolini, and Teles (2002) for the case in which profits are not fully taxed. Profits from period 1 on are the same under flexible and sticky prices. It is just period 0 profits that can be different. It can be shown that there are enough instruments to make those profits equal under flexible and sticky prices.

${ }^{6}$ The profits in period $t$ are priced by $Q\left(s^{t+1} \mid s^{t-1}\right)$ because they can be used for consumption only in the subsequent period. The firms maximize the value of profits net of taxes. For $\tau^{d}\left(s^{t}\right)=1$, the production decisions are indeterminate. We consider the limiting case as $\tau^{d}\left(s^{t}\right)$ approaches one. 
${ }^{7}$ Without full profit taxation, this equivalence breaks down, but our results do not (see Correia et al. [2002] for details).

${ }^{8}$ The notation makes explicit that the set of implementable allocations depends on the degree of price stickiness.

${ }^{9}$ See Adão et al. (2003) for an example in which, because of the restrictions on fiscal policy, the optimal allocation under sticky prices is superior to the optimum under flexible prices.

${ }^{10}$ As we show in Sec. V, the relaxed set $\Omega^{R}$ can be interpreted as the set of implementable allocations when good-specific consumption taxes can be levied.

${ }^{11}$ See the discussion at the end of Sec. II on productive efficiency. The expression $\int_{0}^{1}\left[p_{i}^{c}\left(s^{t}\right) / P^{c}\left(s^{t}\right)\right]^{-\theta} d i$ is the measure of productive inefficiency due to price dispersion.

${ }^{12}$ The relaxed set also contains allocations that cannot be implemented under sticky prices, since that set allows for general configurations of quantities of each good, and part b of lemma 1 implies that under sticky prices there are only two possible quantities or prices in each state.

${ }^{13}$ Correia et al. (2002) solve the model with Calvo staggered pricing.

${ }^{14}$ Neither $\Omega^{\text {Stag }}(\gamma)$ nor $\Omega^{s}(\alpha)$ is a proper subset of the other.

${ }^{15}$ The optimal allocation in this set, as shown in an example calibrated to the U.S. postwar economy in Chari et al. (1991), may be implemented with a very volatile price level.

${ }^{16}$ These are the conditions for uniform taxation of consumption goods, and the nominal interest rate is an additional tax on cash goods on top of the consumption tax that is common to both goods. 


\section{APPENDIX}

\section{Appendix 1: Good specific taxes}

When consumption taxes can discriminate across goods, they are indexed by $i, \tau_{i}^{c}\left(s^{t}\right)$, and the price of good $i$ gross of consumption taxes is $p_{i}^{c}\left(s^{t}\right)=\left[1+\tau_{i}^{c}\left(s^{t}\right)\right] p_{i}\left(s^{t}\right)$. The equilibrium conditions are the ones stated in Section II, except for the price-setting conditions of the firms that set prices in advance, (25). The prices set by those firms can now differ across firms, depending on how they are taxed. They are $p_{s i}\left(s^{t-1}\right)$ :

$$
p_{s i}\left(s^{t-1}\right)=\frac{\theta}{(\theta-1)} E_{t-1}\left[v_{i}\left(s^{t}\right) \frac{W\left(s^{t}\right)}{A\left(s^{t}\right)}\right], t \geq 1
$$

where

$$
v_{i}\left(s^{t}\right)=\frac{u_{C_{2}}\left(s^{t}\right)\left[P^{c}\left(s^{t}\right)\right]^{\theta-1}\left[1+\tau_{i}^{c}\left(s^{t}\right)\right]^{-\theta} A\left(s^{t}\right) N\left(s^{t}\right)}{E_{t-1}\left\{u_{C_{2}}\left(s^{t}\right)\left[P^{c}\left(s^{t}\right)\right]^{\theta-1}\left[1+\tau_{i}^{c}\left(s^{t}\right)\right]^{-\theta} A\left(s^{t}\right) N\left(s^{t}\right)\right\}} .
$$

The set of implementable allocations when tax instruments are completed to include goodspecific taxes is described in the following proposition.

Proposition 5. The set of implementable allocations $\left\{C_{1}\left(s^{t}\right), C_{2}\left(s^{t}\right), N\left(s^{t}\right)\right\}_{t=0}^{\infty}$, and relative prices $p_{i}^{c}\left(s^{t}\right) / P^{c}\left(s^{t}\right)$, with discriminatory consumption taxes under any degree of price rigidity, $0 \leq \alpha<1$, is characterized by the implementability conditions (33), (34), and the feasibility conditions

$$
\left[C_{1}\left(s^{t}\right)+C_{2}\left(s^{t}\right)+G\left(s^{t}\right)\right] \int_{0}^{1}\left[\frac{p_{i}^{c}\left(s^{t}\right)}{P^{c}\left(s^{t}\right)}\right]^{-\theta} d i=A\left(s^{t}\right) N\left(s^{t}\right)
$$


where the relative prices $p_{i}^{c}\left(s^{t}\right) / P^{c}\left(s^{t}\right) \geq 0$ satisfy the restriction

$$
\left\{\int_{0}^{1}\left[\frac{p_{i}^{c}\left(s^{t}\right)}{P^{c}\left(s^{t}\right)}\right]^{1-\theta}\right\}^{\frac{1}{1-\theta}}=1 .
$$

Proof:

The equilibrium conditions restricting the variables $\left\{C_{1}\left(s^{t}\right), C_{2}\left(s^{t}\right), N\left(s^{t}\right)\right\}_{t=0}^{\infty}$, as well as $\left\{R\left(s^{t}\right), P^{c}\left(s^{t}\right), \bar{B}^{g}\left(s^{t}\right), M\left(s^{t}\right), \tau^{n}\left(s^{t}\right), W\left(s^{t}\right)\right\}_{t=0}^{\infty}$ and $\left\{p_{i}^{c}\left(s^{t}\right), \tau_{i}^{c}\left(s^{t}\right), p_{i}\left(s^{t}\right), p_{s i}\left(s^{t}\right), p_{f}\left(s^{t}\right)\right\}_{t=0}^{\infty}$, are the household marginal conditions (13), (14), (16); the cash-in-advance constraints (9); the budget constraints (19); the price-setting equations for the flexible price and sticky price firms, respectively, (22) and (A.1); the feasibility conditions (A.2); the restriction for the price level (A.3); $p_{i}^{c}\left(s^{t}\right)=\left[1+\tau_{i}^{c}\left(s^{t}\right)\right] p_{i}\left(s^{t}\right) ; p_{i}\left(s^{t}\right)=p_{s i}\left(s^{t}\right)$ for $i \in[0, \alpha]$, which are the sticky price firms with measure $\alpha ; p_{i}\left(s^{t}\right)=p_{f}\left(s^{t}\right)$ for $i \in(\alpha, 1]$; as well as the restriction that the nominal interest rate be nonnegative (34).

The equilibrium values for $\left\{c_{1 i}\left(s^{t}\right), c_{2 i}\left(s^{t}\right)\right\}_{t=0}^{\infty}$ and $\left\{g_{i}\left(s^{t}\right)\right\}_{t=0}^{\infty}$ are obtained using the demand functions (11), (12), and (20). The $\left\{\bar{B}\left(s^{t}\right), B\left(s^{t+1}\right)\right\}_{t=0}^{\infty}$ are obtained with the marketclearing conditions (29) and (30). The prices of the state-contingent debt in zero net supply, $Q\left(s^{t+1} \mid s^{t}\right)$, are given by (15).

We will now show that the only restrictions on the allocations $\left\{C_{1}\left(s^{t}\right), C_{2}\left(s^{t}\right), N\left(s^{t}\right)\right\}_{t=0}^{\infty}$ and ratios $\left\{p_{i}^{c}\left(s^{t}\right) / P^{c}\left(s^{t}\right)\right\}_{t=0}^{\infty}$ are the implementability condition (33), which is condition (19) for $t=0$; the condition for a nonnegative interest rate (34); the feasibility conditions (A.2); and the conditions for the price level (A.3). The other equilibrium conditions restrict the remaining variables $\left\{R\left(s^{t}\right), P^{c}\left(s^{t}\right), \bar{B}^{g}\left(s^{t}\right), M\left(s^{t}\right), \tau^{n}\left(s^{t}\right), W\left(s^{t}\right)\right\}_{t=0}^{\infty}$ and $\left\{p_{i}^{c}\left(s^{t}\right), \tau_{i}^{c}\left(s^{t}\right), p_{i}\left(s^{t}\right), p_{s i}\left(s^{t}\right), p_{f}\left(s^{t}\right)\right\}_{t=0}^{\infty}$.

The household marginal conditions on the choice of cash and credit goods, (13), determine 
the nominal interest rates, $\left\{R\left(s^{t}\right)\right\}_{t=0}^{\infty}$, which are nonnegative because of $(34)$. Let $P^{c}\left(s_{0}\right)$ be given, and let $\Phi_{t}$ be the number of states in period $t$, with $\Phi_{0}=1$. For any $t \geq 1$, given the values for $P^{c}\left(s^{t-1}\right)$, there are $\Phi_{t-1}$ intertemporal constraints (16) and $\Phi_{t}$ constraints (19) to determine $\Phi_{t}+\Phi_{t-1}$ variables, the price levels gross of consumption taxes and the state-noncontingent asset levels, $P^{c}\left(s^{t}\right)$ and $M\left(s^{t-1}\right)+R\left(s^{t-1}\right) \bar{B}^{g}\left(s^{t-1}\right)$. The money supply in period $t$ and state $s^{t}$ can be determined using the cash-in-advance constraint, (9), if it holds with equality.

To simplify, we now assume that the labor income tax rates are zero, $\tau^{n}\left(s^{t}\right)=0$. From the household intratemporal conditions, (14), we obtain the path for the nominal wage, $\left\{W\left(s^{t}\right)\right\}_{t=0}^{\infty}$. From the price-setting conditions for the flexible price firms, (22), we obtain $\left\{p_{f}\left(s^{t}\right)\right\}_{t=0}^{\infty}$. Given $\left\{P^{c}\left(s^{t}\right)\right\}_{t=0}^{\infty}$ and $\left\{p_{i}^{c}\left(s^{t}\right) / P^{c}\left(s^{t}\right)\right\}_{t=0}^{\infty},\left\{p_{i}^{c}\left(s^{t}\right)\right\}_{t=0}^{\infty}$ are determined. From the price-setting conditions for the sticky price firms, (A.1), together with $p_{i}^{c}\left(s^{t}\right)=\left[1+\tau_{i}^{c}\left(s^{t}\right)\right] p_{i}\left(s^{t}\right)$, we obtain $\left\{\tau_{i}^{c}\left(s^{t}\right), p_{i}\left(s^{t}\right)\right\}_{t=0}^{\infty}$. 